\title{
The expression of neotectonics in the Pantanal da Nhecolândia, State of Mato Grosso do Sul - Brazil
}

\section{ANA PAULA G. OLIVEIRA ${ }^{1}$, RÔMULO MACHADO ${ }^{2}$, ALISSON A. RIBEIRO ${ }^{3}$, CAMILA L. MIOTO ${ }^{4}$, JOSÉ $^{3}$ MARCATO JÚNIOR ${ }^{3}$, ANTONIO R. SAAD ${ }^{5}$, JOEL B. SÍGOLO ${ }^{2}$ and ANTONIO C. PARANHOS FILHO ${ }^{3}$}

\author{
${ }^{1}$ Programa de Mestrado em Análise Geoambiental, Universidade de Guarulhos/ \\ UNG, Praça Tereza Cristina, 239, 07023-070 Guarulhos, SP, Brazil \\ ${ }^{2}$ Universidade de São Paulo, Instituto de Geociências, Rua do Lago, 562, Butantã, 05508-080 São Paulo, SP, Brazil \\ ${ }^{3}$ Laboratório de Geoprocessamento para Aplicações Ambientais, Faculdade de Engenharias, Arquitetura e Urbanismo e Geografia, \\ Universidade Federal de Mato Grosso do Sul, Unidade 7A, Cidade Universitária, s/n, 79070-900 Campo Grande, MS, Brazil \\ ${ }^{4}$ Laboratório de Geoprocessamento, Instituto de Ciências Agrárias e Tecnológicas, Universidade Federal de Mato Grosso, \\ Campus Universitário de Rondonópolis, MT 270, Km 06, Sagrada Família, 78735-901 Rondonópolis, MT, Brazil \\ ${ }^{5}$ Geólogo autônomo, Rua Professor Lúcio Martins Rodrigues, 6, Morumbi, 05621-025 São Paulo, SP, Brazil
}

Manuscript received on June 22, 2017; accepted for publication on October 4, 2017

\begin{abstract}
Pantanal da Nhecolândia is one of the most well-preserved areas in the State of Mato Grosso do Sul. Located in the southern part of the Taquari River megafan, it is in tectonic contact with the fault escarpments of the Maracaju-Campo Grande plateaus to the east and with the fault escarpments of the Bodoquena plateau to the west, which continue to north. To the south and to the north, the limits are marked respectively by the lineaments of the Negro and Taquari Rivers. Nhecolândia is characterized by the existence of at least 17,631 lagoons, 17,050 (96.70\%) of which are of fresh water (baias) and 577 (3.3\%) of salty water (salinas). Studies based on (Landsat) satellite images and use of free software (QGIS, version 2.8.3) and GIS (Geographic Information Systems) revealed that the major axes of the lagoons are aligned along two directions, NE (62.49 \%) and NW (37.51\%), with modes concentrated between N30-40E and N30-40W, suggesting in both cases the role played by tectonic control (neotectonics) in their formation. Evidences of fluvial origin are presented for these groups of lagoons, as well as for their tectonic alignment.
\end{abstract}

Key words: structural lineaments, Nhecolândia, lagoon alignment, Landsat Images, QGIS.

\section{INTRODUCTION}

Branner (1912) is probably responsible for the first reference to seismicity in Pantanal, in the State of Mato Grosso do Sul (Brazil). Nevertheless, it was only after more than half a century that the first seismic records have been obtained, thanks to the

Correspondence to: Ana Paula Garcia Oliveira

E-mail: apg.bio@gmail.com installation of the first seismographic stations in Brazil, which aided the preliminary studies for the delimitation of the areas of highest seismic activity in the country and, consequently, in Pantanal. Agreat impulse in this sense took place with the installation of the Brazilian Seismographic Net (BRASIS) in 2010, including the Aquidauna seismographic station in the southern part of Pantanal. Another important impulse was the implementation of 
the Portal of the National Seismologic System in 2014, which made the real-time transmission of seismographic data possible. The map of seismic activity distribution in Brazil shows that Pantanal is one of the regions with the highest earthquake concentrations in the country, that is a region with active seismicity, as suggested by several authors (Assine 2010, Assine and Soares 2004, Hasui 1990, 2010, Assumpção and Suaréz 1988, Assumpção et al. 2009a, b, Facincani et al. 2011, Zani and Assine 2011).

The strongest earthquake recorded in Pantanal occurred in its southern part, in the vicinity of Miranda in 1964, reaching magnitude 5.4 on the Richter scale. In 2010, the second strongest earthquake recorded in the region occurred in Coxim in the eastern part of Pantanal, reaching magnitude 4.8 on the Richter scale. Both earthquakes were associated with inverse fault activity (Facincani et al. 2012, Assumpção and Suárez 1988, Assumpção et al. 2009). Earthquake records have been obtained in the vicinity of Nhecolândia, in special close to the limit between Paiguás and Nhecolândia (Almeida et al. 2015).

Seismic activity in Pantanal has been interpreted as the result of recent tectonic reactivations of the Transbrasiliano Lineament (Soares et al. 1998, Riccomini and Assumpção 1999, Assine 2004, Assine and Soares 2004, Facincani 2007, Facincani et al. 2011, 2012, Paranhos Filho et al. 2013).

Despite Pantanal is characterized by yearly flooding, some aspects confer distinct characteristics to it, which is the reason why its division in subregions named "Pantanais" is justified. The number of sub-regions varies from author to author, with some recognizing the existence of 18 different Pantanais (Mioto et al. 2012).

Nhecolândia, with an area of $20,210 \mathrm{~km}^{2}$ (Mioto et al. 2012), represents the largest subregion of Pantanal, being its main characteristic the presence of more than 17,000 lagoons. Although this immense quantity of lagoons is concentrated in the tropical region, some present alkaline or even brackish waters. It is considered the best preserved region of Pantanal from the environmental point of view, which highlights its importance as a preserved ecosystem. Despite the countless studies carried out in Pantanal, the genesis of its lagoons and their evolution are still debatable issues in the scientific community.

Many lagoons are aligned along two main directions: a predominating NE-SW and a subordinated NW-SE. These two directions are compatible with the structural directions described by Paranhos Filho et al. (2013) for the Pantanal region. It is worth pointing out that the limits of Nhecolândia coincide with major lineaments.

In this study, the structural behavior of 17,613 lagoons in Nhecolândia was investigated on the basis of information obtained from remote sensing, use of (Landsat) satellite images, geographic information systems (GIS) and of the software QGIS, version 2.8.3 (QGIS Development Team 2015), with the objective of presenting a general scenario of these features and discussing their origin.

\section{MATERIALS AND METHODS}

Nhecolândia occupies the southern part of the Taquari River megafan, located north of the Pantanal do Negro (Fig. 1). Alluvial fans are deposits formed by the sudden change of fluvial regime, from rocky bed to alluvial. Regarding Nhecolândia, this change is attributed to the presence of the Pantanal Escarpment, which corresponds to a nearly N-Strending tectonic structure associated with the formation of the eastern border of the Pantanal Basin.

The information for this study was mainly obtained from remote sensing data, such as Landsat images freely available from the Instituto Nacional de Pesquisas Espaciais online catalog (INPE http://www.dgi.inpe.br/CDSR/) and from free Geographic Information Systems (GIS). 


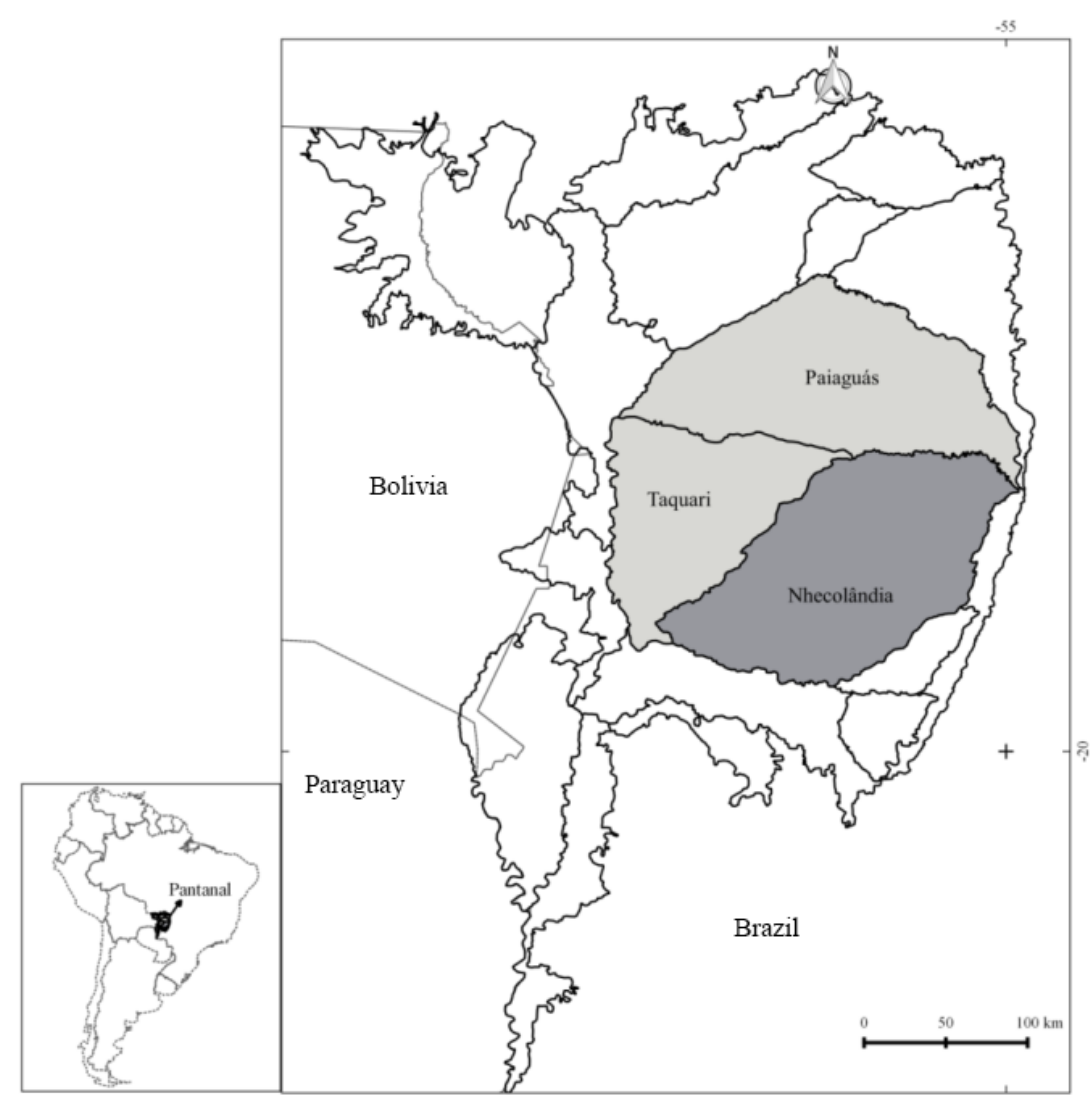

Figure 1 - Nhecolândia limits. The three Pantanal sub-regions (Nhecolândia, Paiaguás and Taquari) that compose the Taquari River alluvial megafan are represented in gray, according to the limits proposed by Mioto et al. (2012).

Software QGIS, version 2.8.3 (QGIS Development Team 2015), was used to photointerpret the images. The free software GIMP (Kimball et al. 2013) was used for the final edition of the figures.

\section{GEOMORPHOLOGIC AND TECTONIC ASPECTS OF PANTANAL}

The Pantanal hydrographic basin, considered one of the largest of the world, occupies - only the Brazilian territory - ca. 1,200,000 km² (Almeida 1945). The Paraguay River drains Pantanal on the western border, the banks rising 2 to $3 \mathrm{~m}$ above the mean level of the river. Sandy isles are common along the river bed, which reach the same heights of the banks (Almeida 1945). According to Almeida (1945), in the Brazilian territory (States of Mato
Grosso and Mato Grosso do Sul), the Paraguay River runs for ca. $770 \mathrm{~km}$, approximately $2 / 3$ of this distance in meandering course, with a mean declivity of $33 \mathrm{~mm} / \mathrm{km}$, which slightly rises (41.3 $\mathrm{mm} / \mathrm{km}$ ) when reaching the Paraguayan Chaco. Along its course in Pantanal, the regime of the Paraguay River is sedimentary and changes to erosional after entering Paraguay (Almeida 1945).

Pantanal is a sedimentary basin inserted in an elongated, NNE-SSW-trending tectonic depression. It is approximately $400 \mathrm{~km}$ long and $250 \mathrm{~km}$ wide and is filled with Cenozoic clastic sediments, reaching $550 \mathrm{~m}$ of inferred thickness (Assine 2004).

A tectonic origin for Pantanal was initially postulated by Almeida (1945), based on geologic and geomorphologic evidences found in the 
Santa Cruz and Urucum ridges, where the author described a relief breakup with the formation of suspended valleys and fault scarps, and identified dip faults with a maximum measured displacement of $300 \mathrm{~m}$ (e.g., the Banda Alta valley fault).

The course of the Paraguay River is sometimes adjusted to faults along the border of the Pantanal Basin. Close to Corumbá, the river strongly deflects $\left(\sim 90^{\circ}\right)$ and runs eastwards, which is a direction conditioned by an approximately E-W-trending fault (Assine 2004).

Such faults were also suggested for the western border of the Bodoquena Plateau, where they constitute abrupt receding escarpments, leading behind a residual relief supported by more resistant rocks on the eastern border of the Gran Chaco (Almeida 1965).

Since the 1950's, faults that caused the subsidence of the Chaco sedimentary basin during the Cenozoic are well known in this region, particularly in the vicinity of the Ipacaraí lake, east of Asunción (Eckel et al. 1959, Almeida 1965). Submeridian-trending faults were also described by Putzer (1962) close to the Apa River mouth, where the Paraguay River would adjust to a tectonic valley.

According to Assine (2004), the eastern border of the basin is also a fault, but the traces of this structure are covered by younger alluvial sediments of the Pantanal Formation, which in turn onlap the basement from west to east, with the erosional regression of the scarps that equally mark the limit of the Maracaju-Campo Grande and TaquariItiquira plateaus. Soares et al. (1998) describe the main basin border fault (Morrinho Fault) and point out the presence of an isolated small elevation of ca. $25 \mathrm{~m}$ above the Pantanal surface, where reddish sandstones, probably from the Alto Garças Formation, are much silicified and contain quartz veinlets, suggesting proximity to the fault plane.

Geophysical studies carried out in Pantanal have confirmed the existence of a relatively thin
$(<500 \mathrm{~m})$ sedimentary basin, developed during the Cenozoic on an attenuated crust of less than $35 \mathrm{~km}$ in thickness (locally $<30 \mathrm{~km}$ ). Probably this feature is older and was inherited from the Precambrian history (Assumpção et al. 2013a, b). Alternatively, this geologic inheritance or part of it can be related to a younger, Eopaleozoic history, with the formation of the Asunción proto-arc (anteclise). The age of installation of this structure is still controversial. Some authors consider it to be Eodevonian (Melo 1989, Almeida 2004), whereas others consider it Neosilurian to Devonian (Fúlfaro et al. 1982), and relate it to a tectonic pulse associated with the Caledonian Orogeny (Zalán et al. 1987). This almost N-S-trending arc, now covered and situated under the Pantanal, divided the Paleozoic Paraná and Chaco basins, when the expansion of the transgression of a sea (or gulf) occurred, from the open ocean towards SW Gondwana (Melo 1989, Almeida 2004).

The subsidence of the Pantanal sedimentary basin was initially attributed to the presence of faults on its borders (Almeida 1945) and later related to flexural subsidence mechanisms, in an analogous way to what occurs in intracratonic sedimentary basins (Shiraiwa 1994, Ussami and Shozo 1999).

More recently, the hypothesis of faultcontrolled tectonic subsidence has been attested by several authors (Soares et al. 1998, Assine 2004, among others), strengthening the role played in the development of the Pantanal landscape as a whole, altering its base levels and topographic gradients. The tectonic evidence is seen in the western side of the Pantanal Basin, where the course of the Paraguay River is at times adjusted to the fault traces that limit the basin. Close to Corumbá, for example, the river starts to be structurally controlled by an E-Wtrending fault, changing its course abruptly.

In the last decades, several authors have associated the Pantanal Basin sedimentation with activities linked to neotectonics and signaled 
that it is a seismically active region, as a reflex of the reactivation of structures associated with the Transbrasiliano Lineament (Riccomini and Assumpção 1999, Soares et al. 1998, Assine 2004, Assine and Soares 2004). NE-trending fault zones were probably active during the Holocene in the central part of Pantanal, as a reflex of the reactivation of such lineament (Rabelo and Soares 1999).

Recently, the analysis of structural lineaments extracted from satellite images of the Pantanal region (CBERS 28 and WFI sensor) has highlighted three structural trends that affect the sedimentary succession: NE, NW and EW, the latter being considered the youngest and reactivated during the Quaternary (Paranhos Filho et al. 2013).

\section{RESULTS AND DISCUSSION}

In the geologic context of the Pantanal Sedimentary Basin, Nhecolândia is part of the Taquari alluvial megafan, stretching out for $269 \mathrm{~km}$ in the N-S direction and $266 \mathrm{~km}$ in the E-W direction (Figures 1 and 2). After the formation of this fan, the regional neotectonics divided it in three distinct domains: the first, to the north, in the Paiaguás region, is higher than the other two, thus, remaining dry, whereas the other two regions are always flooded (Figure 2); the second, in the central part of the structure, is the present, still active lobe of the Taquari River, which is also tectonically controlled (Assine and Soares 2004, Assine 2003, Rabelo and Soares 1999), and corresponds to a region that remains covered by a water layer or flooded the whole year.

The third domain, in the southern part of the megafan, is Nhecolândia (Figure 3). It is limited to the north by the Taquari River and to the south by the Negro River, which, in turn, is also controlled by a lineament that stretches westwards, towards the Andes, where it is known as Tucavaca Lineament or Negro River Lineament (Mendes et al. 2006, Mendes 2008). The Nhecolândia eastern limit is

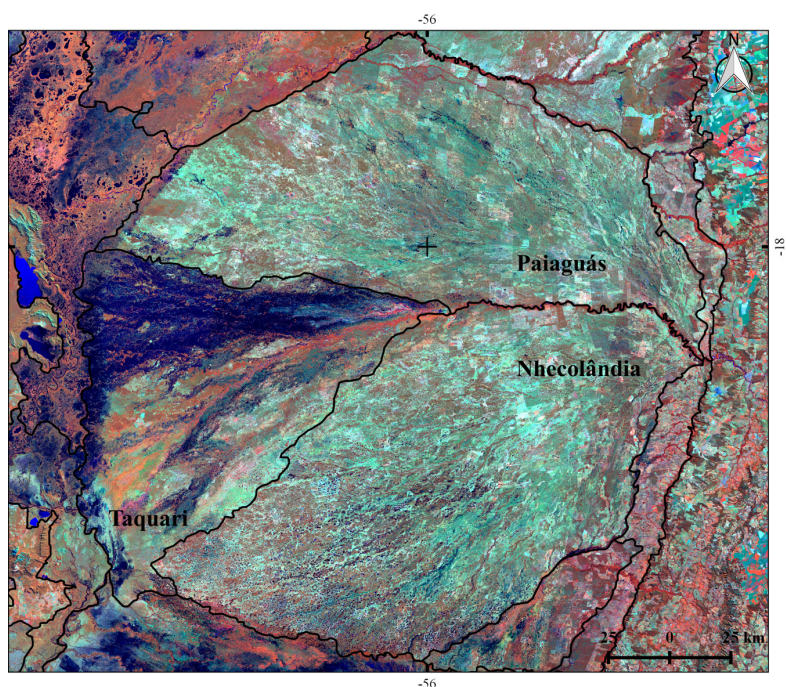

Figure 2 - Mosaic of de Landsat 8 images, sensor OLI, obtained during the dry season, false-color composition, RGB 564, showing the difference between the three Pantanais that form the Taquari fan (Earth Explorer 2013a-i). The Pantanal do Taquari, characterized by the present Taquari lobe, remains flooded (represented in dark blue) during the whole year.

the Pantanal Ridge scarp, also named MaracajuCampo Grande and Taquari-Itiquira, which is the tectonic limit between the Pantanal and Paraná sedimentary basins (Assine 2004). In this sense, all Nhecolândia physical limits are structural.

Oliveira (2014), using the object-oriented classification of Landsat 5 images, TM sensor, quantified 17,631 lagoons throughout Nhecolândia (Figure 4). Regionally, the fresh water lagoons are called baias (bays), whereas those of brackish or alkaline waters are knowns as salinas. The baias are separated from one another by elevations named cordilheiras (cordilleras), which never exceed $3 \mathrm{~m}$ in relation to the baias (Almeida 1945). These features are typical of the central part of Nhecolândia, which disappear in the vicinities of the Paraguay River. The soil is more clayey and they are in general dry or water is scarce (Almeida 1945).

Out of the total number of lagoons, 17,050 (96.70\% of the total) were classified as baias and $577(3.3 \%)$ as salinas. This number is twice as high as the expected, considering the authors 


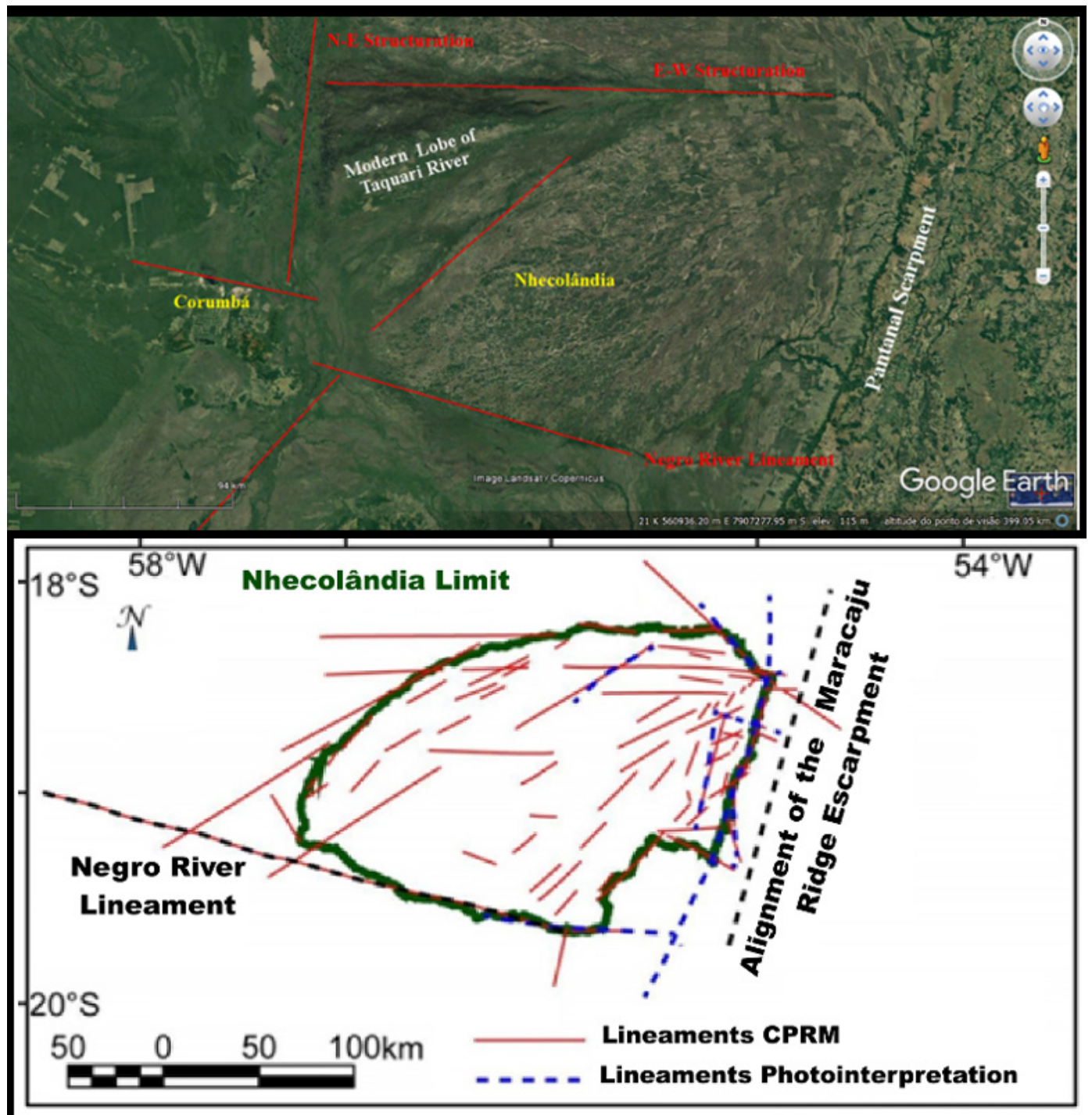

Figure 3 - Markedly structural Nhecolândia limits. To the south the limit is the Negro River, adjusted to the Negro River Lineament (continuity of the Tucavaca Lineament). The western limit coincides with the NE structuration that crosscuts Pantanal and once controlled the Taquari River. To the north it is limited by an E-Wtrending structure that controls the present Taquari River course. The eastern limit is related to the Pantanal Basin limit.

who worked in the region previously: Fernandes (2007) described more than 9,000 lagoons; Assine (2010) identified ca. 10,000 lagoons, and Furquim et al. (2010) 8,500 lagoons, being 7,000 baias and 1,500 salinas, showing a baías/salinas relationship different from that described by Oliveira (2014).

The analysis of the contours of the vector polygons of the lagoons and their axes show that they are aligned and that the salinas are not distributed at random; on the contrary, they are clustered and aligned according to a NE trend, particularly in the southeastern sector of the megafan.

From the vector contour the lagoon major axis trends were obtained and the circularity ratio was calculated for all lagoons.

The generated rose diagrams show that $62.49 \%$ of the lagoon major axes trend NE and are concentrated in the $20^{\circ}-50^{\circ}$ interval, with mode between $\mathrm{N} 30^{\circ}-40^{\circ} \mathrm{E}$, as seen in Figure 5 . 


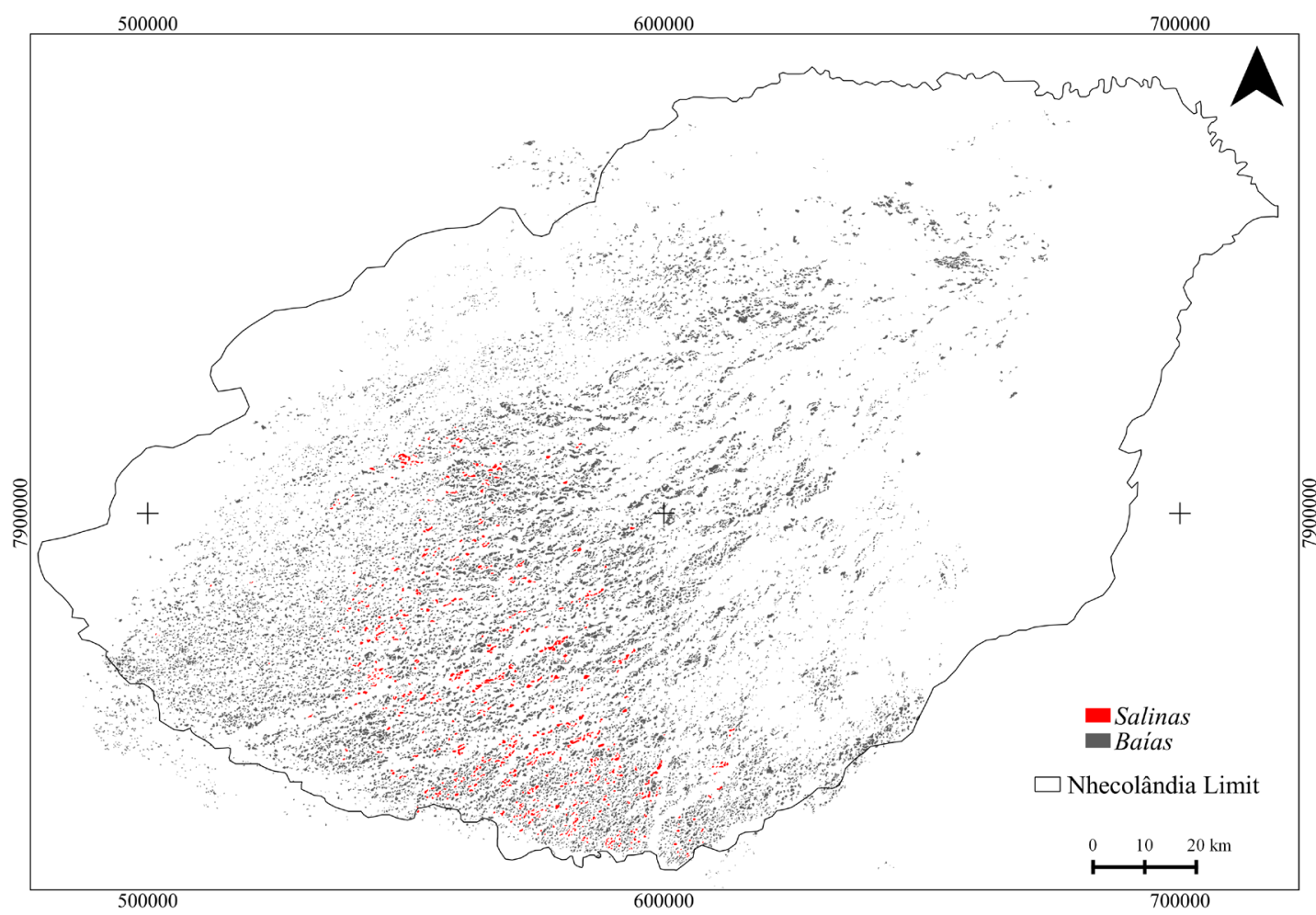

Figure 4 - Result of the object-oriented classification of Nhecolândia. 17,631 lagoons were identified, being 17,050 (96.70\% of the total) classified as baias and 577 (3.3\%) as salinas (Oliveira 2014).
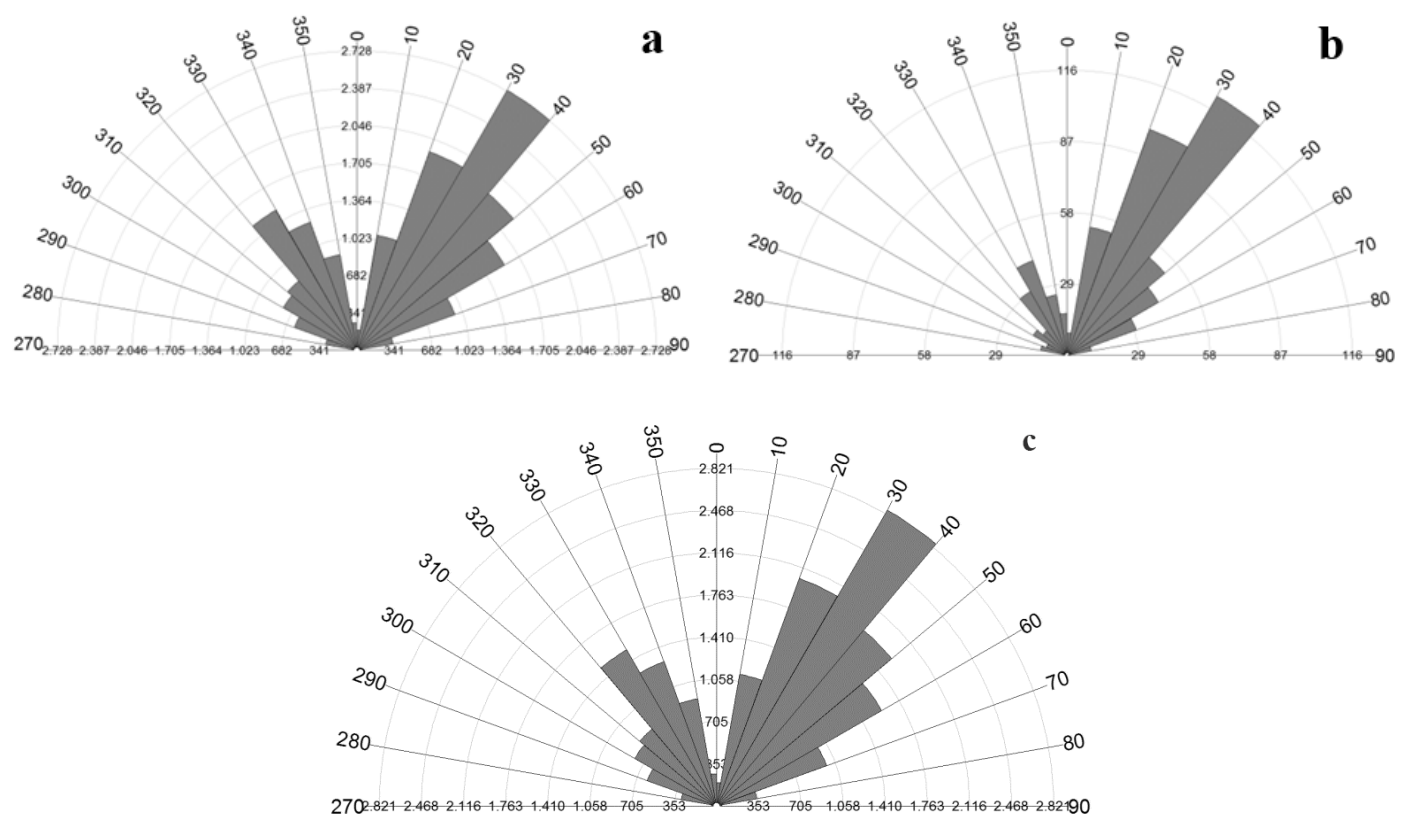

Figure 5 - Trend of the major axes of the Nhecolândia lagoons, showing a clear alignment between them (Oliveira 2014). a: Rose diagram showing the alignment of all Nhecolândia lagoons $(n=17,631)$. Two preferential trends, $\mathrm{N} 30^{\circ}-40^{\circ} \mathrm{E}\left(62.5 \%\right.$ between $20^{\circ}$ and $\left.50^{\circ} \mathrm{NE}\right)$ and $\mathrm{N} 30^{\circ}-40^{\circ} \mathrm{W}$, are observed. b: Trend of the baias $(\mathrm{n}=17,050)$, with highest frequencies in the $\mathrm{N} 20^{\circ}-50^{\circ} \mathrm{E}$ and $\mathrm{N} 20^{\circ}-40^{\circ} \mathrm{W}$ interval. c: Trend of the salinas $(\mathrm{n}=577)$, with the highest frequencies in the $\mathrm{N} 20^{\circ}-40^{\circ} \mathrm{E}$ and $\mathrm{N} 30^{\circ}-40^{\circ} \mathrm{W}$ interval. 
A second axis concentration trends NW $\left(\mathrm{N} 30^{\circ}-\right.$ $\left.40^{\circ} \mathrm{W}\right)$. The highest frequency of trends for baias is between $\mathrm{N} 20^{\circ}-50^{\circ} \mathrm{E}$ and $\mathrm{N} 30^{\circ}-40^{\circ} \mathrm{W}$, whereas for salinas the interval is more restricted in the $\mathrm{NE}$ direction (between $\mathrm{N} 20^{\circ}-40^{\circ} \mathrm{E}$ ) and the similar in the NW direction $\left(\mathrm{N} 30^{\circ}-40^{\circ} \mathrm{W}\right)$, thus being indistinguishable, when it comes to alignment (see Fig. 5b, c).

Considering the hypothesis that the shape of the lagoons is close to a perfect cycle, this could create a certain confusion regarding the real direction of the major axis and consequently put in check the existence of an alignment, in particular a bi-modal one. The circularity ratio was, then, calculated for the lagoons, resulting in new rose diagrams only for ratios lower than 0.85 and 0.75 (1.0 would be a perfect circle), As shown in Figure 6 , the rose diagrams are similar, attesting the bimodal orientation of the lagoons.

Comparing the frequency of baia alignments (Fig. 5b) with that of salinas (Fig. 5c), slight differences, which are not by chance, are observed. The alignments are more frequent between azimuths $10^{\circ}$ and $60^{\circ}$, which correspond to the orientation of the lagoons.

When interpreting the alignment of lagoons, a fact to be considered is that the Taquari megafan has been built by a sedimentary flow with radial distribution from the entrance point of the Taquari River to the Pantanal plain, from the beginning of its construction to the present (Figure 7).

In this sense, the radial configuration of the structure of the Nhecolândia alluvial fans was conditioned by the geometry of the megafan itself, so that the alignment of the lagoons was apparently induced by the radial geometry of its alluvial fans (paleochannels and marginal paleodikes, for example).

Thus, after testing the type of alignment that exists in the interior of Nhecolândia, it was observed that the compatible pattern is NE-trending

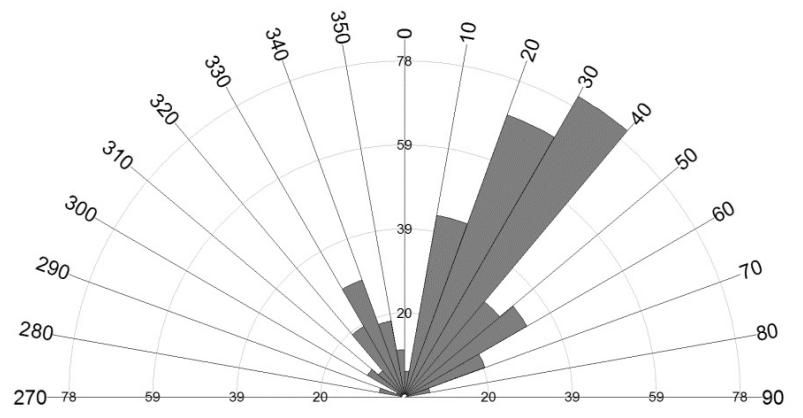

Figure 6 - Rose diagram for lagoons yielding IC $\leq 0.75$. Even discarding lagoons whose shape is close to a perfect circle, the orientation pattern is kept (Oliveira 2014). A test with lagoons yielding IC $\leq 0.85$ resulted in a similar rose diagram.

axes parallel to each other (Figure 8), and not just part of a radial pattern.

Based on the Kolmogorov-Smirnov normality test (Chakravarty et al. 1967), the distribution of axis sizes for baias and salinas is not normal for $p<2.2 * 10^{-16}$. For the comparison between the two axis populations, the Mann-Whitney-Wilcoxon non-parametric test was used (Kruskal 1957), with significance level of $0.05\left(p<2.2 * 10^{-16}\right)$. The data obtained show that there is a significant difference of axis sizes for baias and salinas and that the mean and median for salinas are higher than those for baías (Table I).

In terms of the evolution of these lagoonal environments, two main phases can be envisaged: (1) the formation of the Taquari megafan with deposits arranged in a radial pattern, typical of fans, resulting in an also radial drainage pattern; (2) in the southern part of the fan, which corresponds to the Nhecolândia domain today, under a dryer conditions compatible with the Pleistocene climatic variations, with scarce or even inexistent vegetation, reworking of sediments previously deposited in the basin under eolian conditions occurred, concomitant with the installation of dune fields.

Evidence of this was observed in drill cores from water well drilling. After the first meters, well 

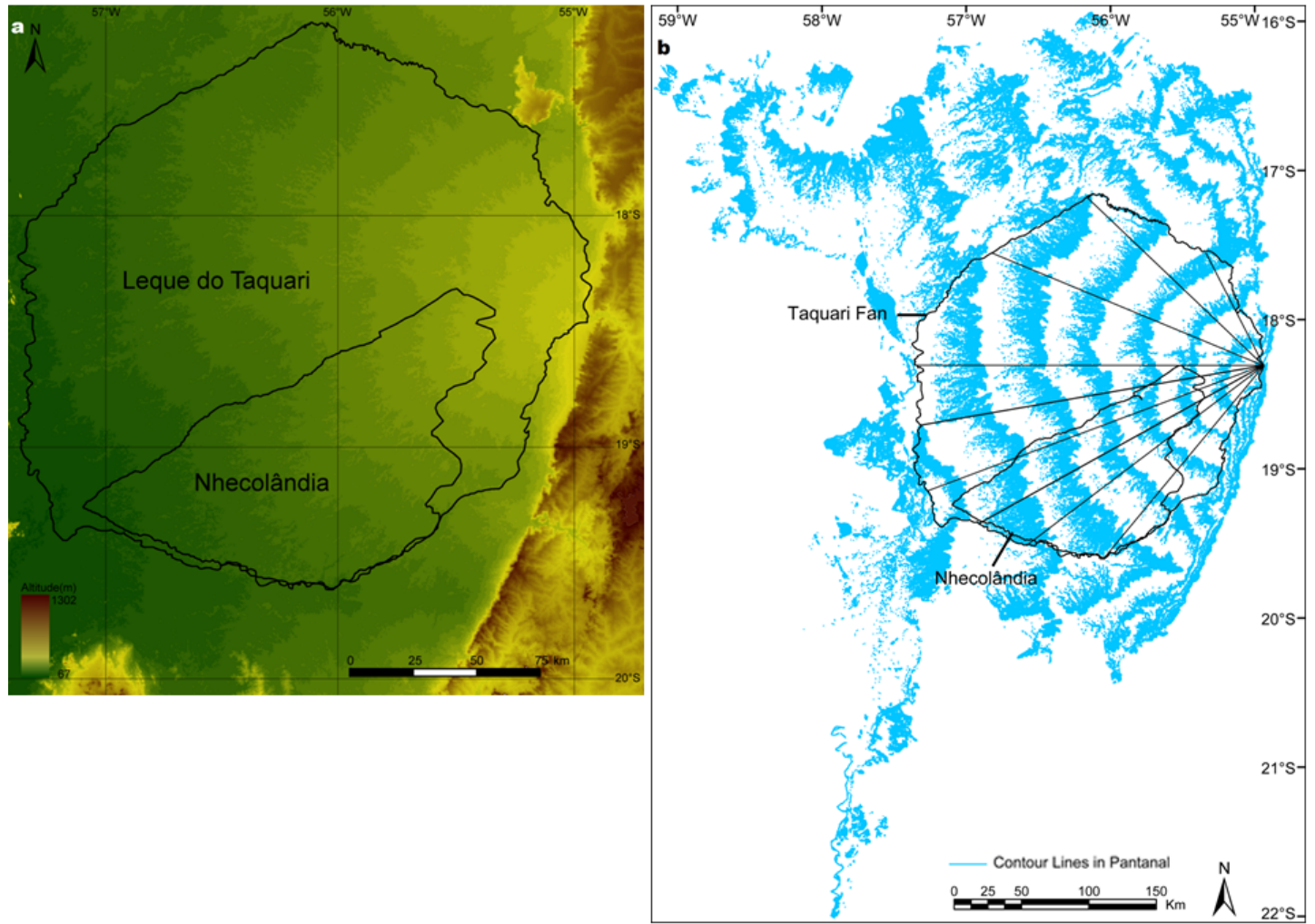

Figure 7 - In (a): hypsometric chart of the Taquari megafan showing the radial pattern of the relief from the Taquari River mouth in Pantanal. In (b): densification of contour lines, highlighting the radial axes from the Taquari River mouth. An alignment of structures of fluvial origin, superposed to Taquari River paleostructures would generate a radial pattern in that region. Both maps were derived from the SRTM digital surface model (Miranda 2005, Oliveira 2014).
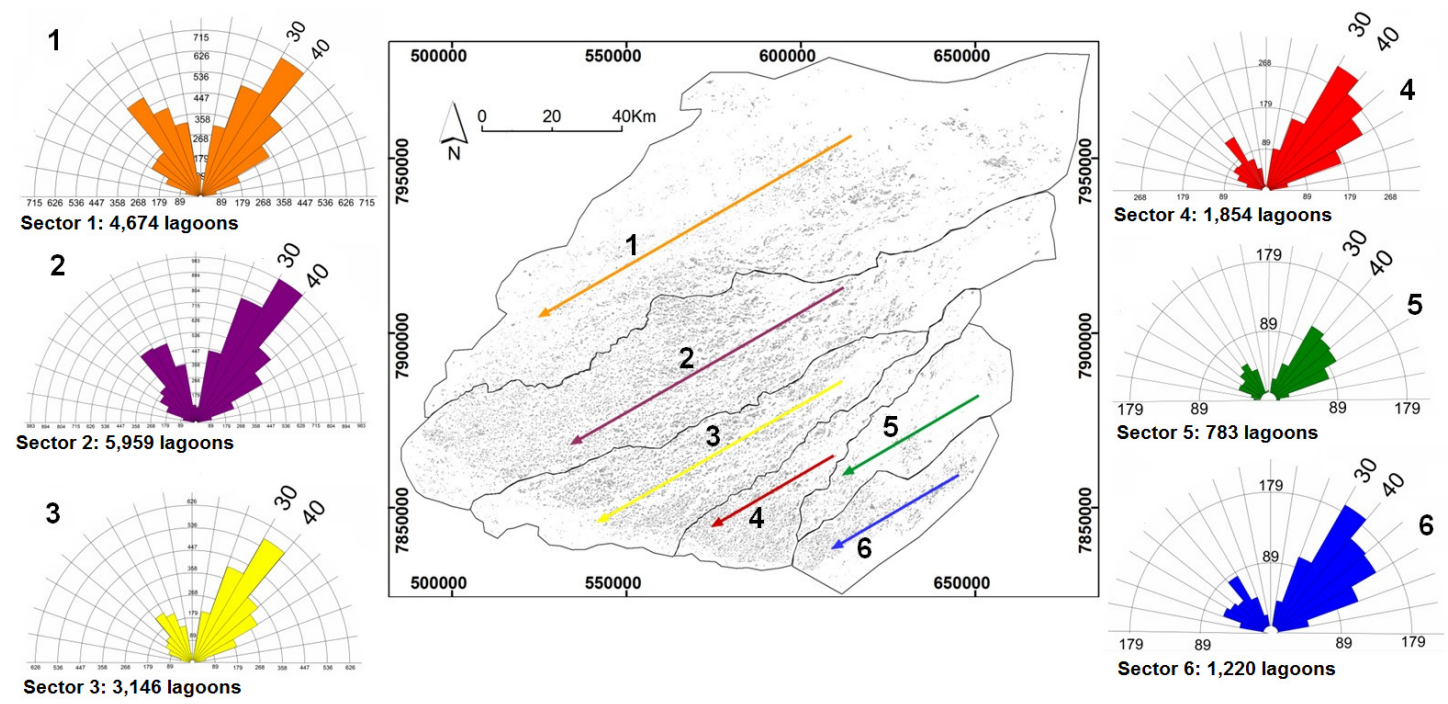

Figure 8 - Nhecolândia was divided in six domains, separated by the main vazantes (downstream areas), with the objective of assessing homogeneous regions, for which the NE (and NW) alignment was tested and resulted compatible in all of them (Oliveira 2014). 
TABLE I

Statistical description of the axis sizes for baías and salinas (Oliveira 2014).

\begin{tabular}{ccccc}
\hline & Mean $(\mathbf{m})$ & Median $(\mathbf{m})$ & Standard Deviation $(\mathbf{m})$ & Population \\
\hline Axes of Baias & 476 & 383 & 331 & 17,050 \\
Axes of Salinas & 704 & 622 & 349 & 581 \\
\hline
\end{tabular}

sorted and rounded sandy sediments were found, showing excellent sphericity and finer-grained than those close to the surface. These features are compatible with eolian deposits, as previously described by Almeida (1945), who characterized them as sediments belonging to the São Bento Series (today Group). On the other hand, more superficial, overlying sediments would result from reworking of older eolian deposits by a fluvial system associated with low sinuosity/meandering rivers (Assine 2008).

After the second phase, a more humid period took place, which promoted the rise of the water table and filling of deflation basins in dune fields, originating the lagoons.

The bimodality of the Taquari fan sands identified by Almeida (1945) suggests eolian deposition (or reworking) during the arid period of the Pleistocene glaciation and the installation of lagoons in the depressions formed by the interdune deflation surfaces, which were filled with water in a more humid climate, related to the rise of the water table (Tricart 1982, Soares et al. 2003, Assine and Soares 2004, Assine 2010).

Luna et al. (2012), studying the lakes formed in Lençóis Maranhenses, showed the formation of lake fields in an eolian environment, although the lakes studied by them are seasonal.

The major axes of the Nhecolândia lagoons have a well-defined NE orientation, with a secondary NW alignment. This alignment could be the record of a secondary direction or of another direction of predominant winds.

Even accepting an eolian origin for the lagoons, when seeking for morphologic similarities between the lakes studied by Luna et al. $(2011,2012)$ and the Nhecolândia lagoons, significant differences are observed, because the lagoons show indications of an origin related to alluvial fan systems.

The analysis of the cordilheiras between the Nhecolândia lagoons reveals the presence of sedimentary structures that suggest paleochannels, which could have participated in the structuration of Nhecolândia. Such structures are compatible with alluvial fan deposits, formed under low sinuosity conditions and as meanders, exhibiting the abandonment of several lobes (Figures 9 and $10)$.

Nhecolândia underwent similar arid conditions at the end of the Pleistocene (Ab'Saber 1988, 2006, Assine 2003), when the lake field formed in association with the alluvial fan system. The paleochannels shown in Figures 9 and 10 repeat themselves throughout Nhecolândia. The bimodal sands that are found in the Taquari River plain were eroded and transported from the plateau where the Botucatu Formation sandstones crop out.

It is worth mentioning that Wilhelmy (1958 in: Ab'Saber 2006) presented a model of lake formation in meandering fluvial systems. The process of fluvial lake formation in Nhecolândia would be analogous. The cordilheiras observed between the lagoons would correspond to marginal paleodikes. The structures of Figure 11 can be identified in Figure 12, obtained from Nhecolândia images.

Nhecolândia and all the Pantanal plain present strong structural control, and the aligned lagoons would result from a fluvial system with structural control in the NE and NW directions, which are presented in the model of Paranhos Filho et al. (2013). Lombardo and Veit (2014), when studying 

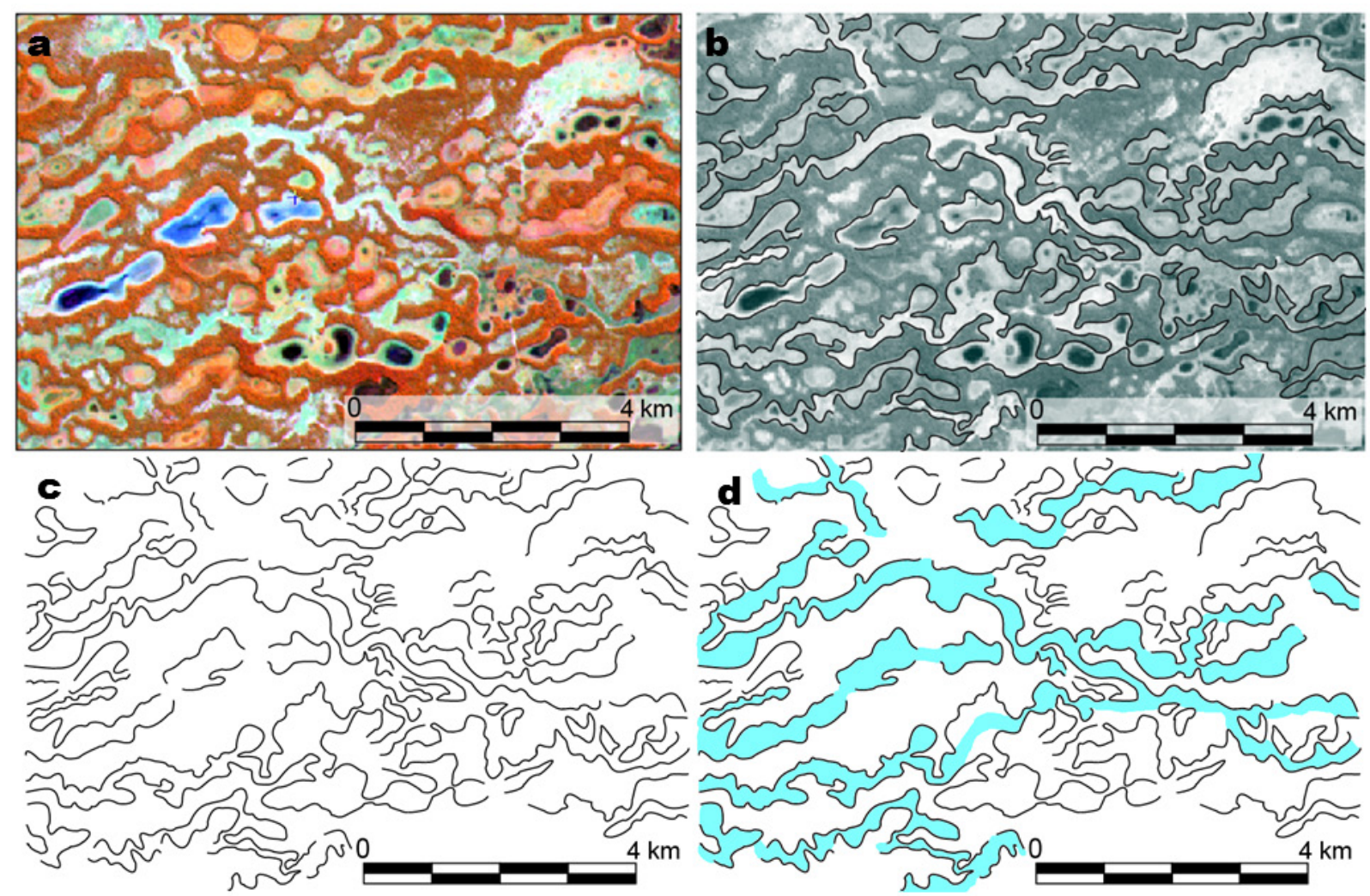

Figure 9 - Landsat 5 image, sensor TM, exhibiting a segment of Nhecolândia with baías, salinas and paleochannels. Image (a) is a false-color (RGB 453) composition. The photointerpretation of the paleochannel limits is shown in (b). In (c), only the limits of the paleochannels of image (b) are represented. In (d) a pattern similar to an anastomosed system is shown.

the oriented lagoons of the Bolivian Amazonia, correlated them with data from lagoons of various regions of the world and concluded that the oriented lakes are of tectonic origin.

The consistent alignment of the Taquari megafan salinas and baias clearly exemplified in the previous rose diagrams is a strong argument in favor of a structural control for the installation and development of these features in Nhecolândia. Their origin is probably related to modern tectonic activity encompassed by neotectonics. An aspect that calls attention is the geometric coincidence between the features described above and the Transbrasiliano Lineament, suggesting that this is a weakness direction that was successively reactivated, thus being a strong candidate for the structural control of salinas and baias. The salinas probably formed later and must correspond to old baias that underwent salinization. In turn, they are younger and were controlled by other structural directions also resulting from modern tectonic reactivations (neotectonics). The angular difference of $60^{\circ}$ that exists between the NE- and $\mathrm{NW}$-trending structures that conditioned the lake orientation is compatible with the reactivation of structure families that exist in the basement of the basin, which could even correspond to a conjugated fracture system and, in this case, the main stress for the generation of these conjugated structures would be oriented close to N-S, and eventually be adjusted in Riedel's Model.

Taking into account the South-American Plate internal displacement model that estimates a NNWtrending velocity of ca. $2 \mathrm{~cm} / \mathrm{year}$ in the Pantanal region, our results are coherent with the alignment 


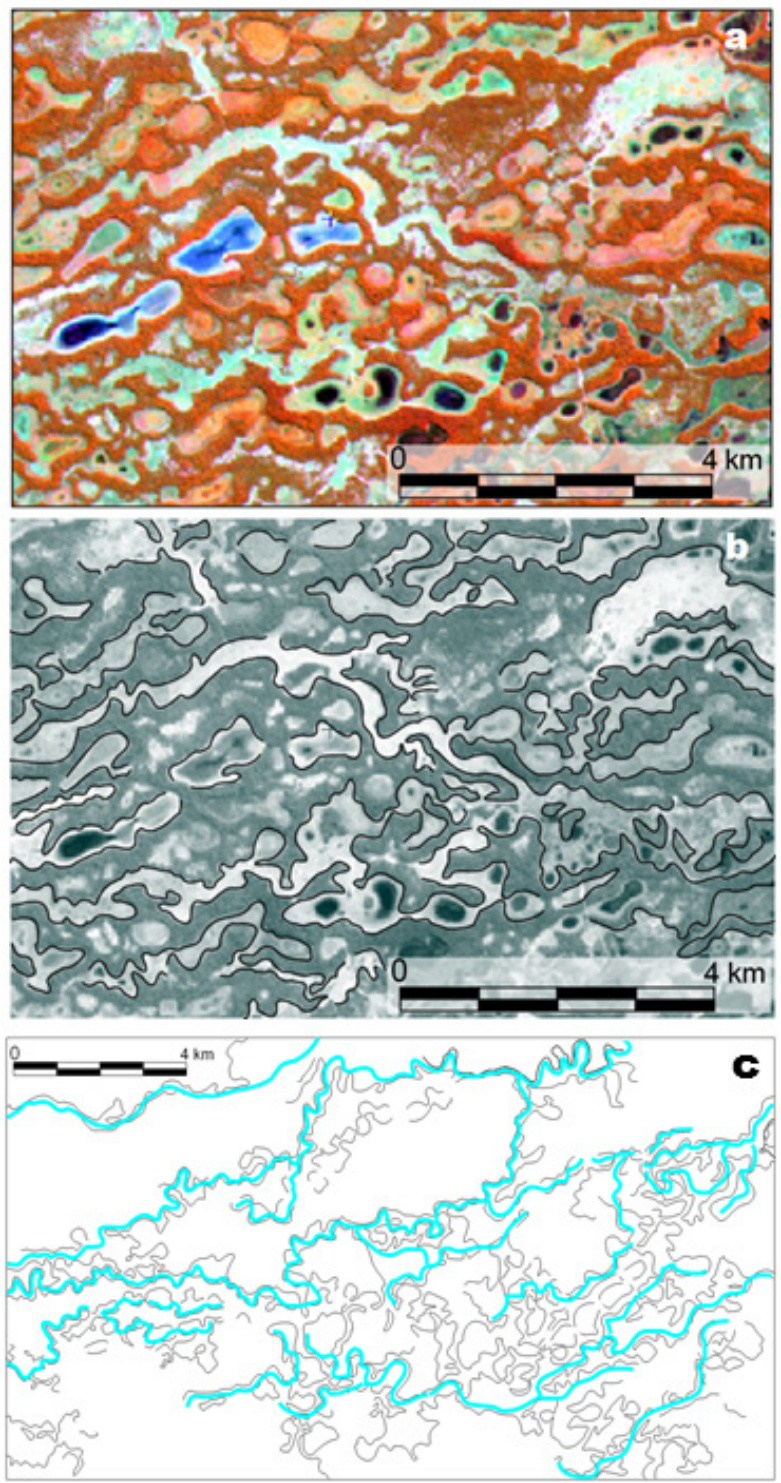

Figure 10 - Landsat 5 image, sensor TM, exhibiting a segment of Nhecolândia with baias, salinas and paleochannels at a smaller scale than the image in Figure 9. Image (a) is a falsecolor (RGB 453) composition. In (b) the photointerpretation of the paleochannel limits is shown. In (c), a pattern similar to an anastomosed system is shown.

displacement observed between baias and salinas, being the Cenozoic time enough for this to happen.

\section{CONCLUSIONS}

This study reiterates the proposals of the existence of tectonic limits in the Taquari megafan, to the east with the scarps of the Maracaju-Campo Grande

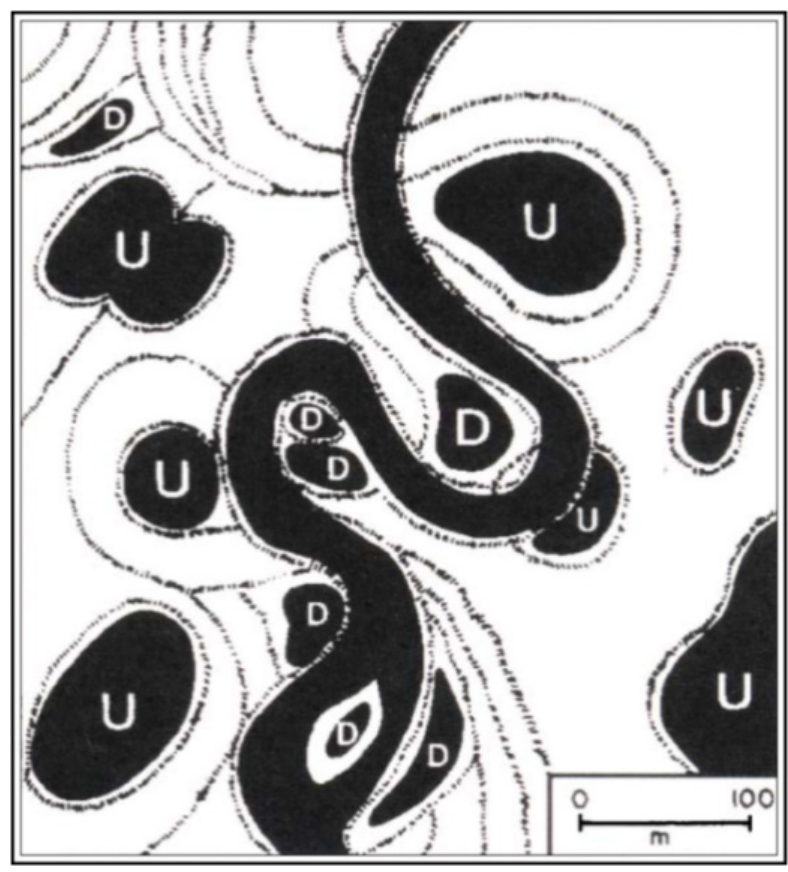

Figure 11 - Types of lakes formed in a fluvial environment, according to Wilhelmy (1958 in: Ab'Saber 2006): lakes in internal meander lobes (U); lakes between imbricated marginal dikes (D).

and Taquari-Itiquira plateaus, to the south with the Negro River lineament, to the west with faults that mark the eastern border of the Bodoquena plateau scarps and that continue northwards and condition the Paraguay River course. These structures continue to the south and constitute the eastern limit of the Paraguayan Chaco.

Three geomorphologic domains were distinguished by the analysis of Landsat 8 (sensor OLI, false-color composition, RGB 564) images (mosaic) of a Taquari megafan region during a dry period: the first in the northern part, named Paiaguás, with higher altitudes; the second, in the central part, corresponding to the present lobe of the Taquari River, still active tectonically, with orientation coinciding with that of the river itself; the third, in the southern part corresponding to Nhecolândia, which is limited to the south by the Negro River, whose course is controlled by a lineament that continues westwards and corresponds to a probable prolongation of the Tucavaca Lineament in Bolivia. 


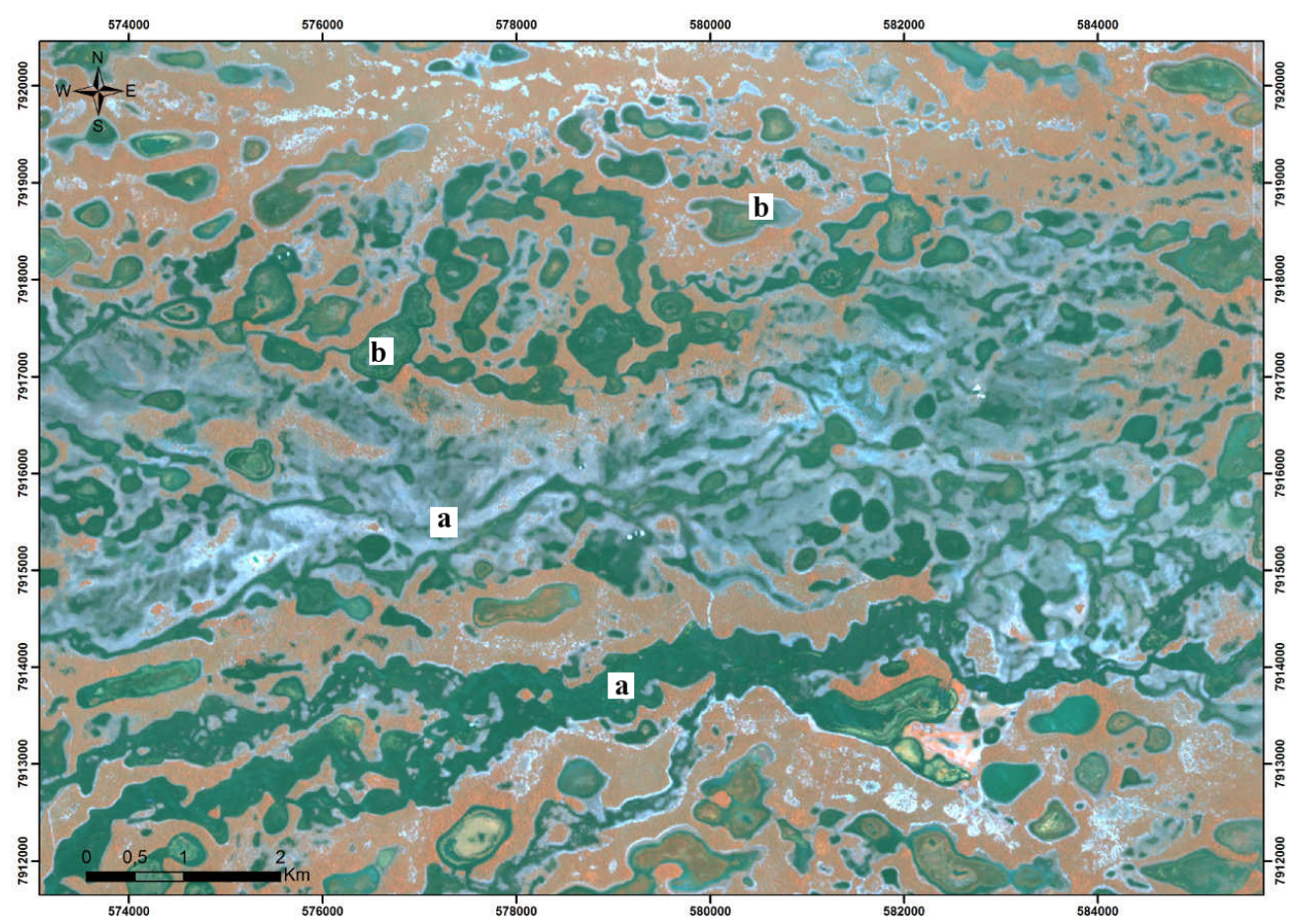

Figure 12 - Image of a flooded area in an ALOS AVNIR-2 scene dated February $2^{\text {nd }}, 2011$ (IBGE 2011). Legend: (a) represents the region occupied by vazantes and (b) corresponds to the region of baias, with links baia/vazante and baia/baia. The water is greenish blue and the vegetation is represented in shades of red. White corresponds to outcrops of the sandy substrate. There is a close relationship between the fluvial system of brooks and vazantes and the lagoons.

From the interpretation of satellite (Landsat) images and the use of free software (QGIS version 2.8.3 2015) and the aid of GIS (Geographic Information Systems), it was possible to statistically analyze the contour vector and major axes of 17,631 lagoons found in Nhecolândia, southern part of Pantanal, out of which 17,050 (96.70\%) are of fresh water and named baias and 577 (3.3\%) of salty water (salinas). The major axes of these lagoons are consistently oriented in the NE (62.49\%) and NW (37.51\%) directions, with modes concentrated between $\mathrm{N} 30^{\circ}-40^{\circ} \mathrm{E}$ and $\mathrm{N} 30^{\circ}-40^{\circ} \mathrm{W}$, suggesting that the two types of lagoons were controlled by structures reflecting existing weakness zones in the Pantanal Basin substrate.

Based on the hypsometric chart, densification of contour lines, and levels derived from the SRTM digital terrain model of the Taquari megafan, a fan-like distribution pattern is evidenced from the
Taquari River mouth that conditioned the radial dispersion of the fluvial sediments westwards, which were controlled in the southern part (Nhecolândia) by the tectonic reactivation of $\mathrm{NE}$ (Transbrasiliano Lineament), NW, and probably E-W structures present in the basin substrate. This reactivation of older structures, contemporaneous with the development of the megafan, was also responsible for the structural control of the two types of lagoons (NE and NW) present in Nhecolândia.

Lastly, it is considered that at least part of the present seismicity of the southern region of Pantanal should be related to the modern tectonic activity (neotectonics) that influenced the installation and evolution of the Taquari River megafan, together with both types - fresh water (baias) and salty (salinas) - of lagoons. 


\section{ACKNOWLEDGMENTS}

To Fundação de Apoio ao Desenvolvimento do Ensino, Ciência e Tecnologia do Estado de Mato Grosso do Sul (FUNDECT) for financing part of this study. To Coordenação de Aperfeiçoamento de Pessoal de Nível Superior (CAPES) for the post-graduation scholarships to Ana P.G. Oliveira and Camila L. Mioto. To Conselho Nacional de Desenvolvimento Científico e Tecnológico (CNPq) for the Produtividade em Pesquisa scholarships (Rômulo Machado: Proc. 300423/82-9, Antonio C. Paranhos Filho: Proc. 305300/2012-1, and Joel B. Sigolo: Proc. 306544/2014-8).

\section{REFERENCES}

AB'SABER AN. 1988. O Pantanal Mato-Grossense e a Teoria dos Refúgios. Rev Bras Geog 2: 9-57.

AB'SABER AN. 2006. Brasil: Paisagens de Exceção. O litoral e o Pantanal Mato-Grossense. Patrimônios Básicos. São Paulo: Ateliê Editorial, 182 p.

ALMEIDA BSDE, MACHADO R, MIOTO CL, OLIVEIRA JRSDE, MARCATO JUNIOR J, SAAD AR, FACINCANI EM AND PARANHOS FILHO AC. 2015. Geotecnologias e sismos no Pantanal. In: Simpósio Nacional de Estudos Tectônicos, 15 - International Symposium on Tectonics, 9. Vitória, ES, p. 404-407.

ALMEIDA FFM. 1945. Geologia do Sudoeste Matogrossense. Boletim. Divisão de Geologia e Mineralogia, Rio de Janeiro: DNPM, 116, 118 p.

ALMEIDAFFM. 1965. Geologia da Serra da Bodoquena (Mato Grosso). Boletim. Divisão de Geologia e Mineralogia, Rio de Janeiro: DNPM, 219, 96 p.

ALMEIDA FFM. 2004. Revisión del limite de la Plataforma Sudamericana em la Argentina. In: Mantesso-Netto et al. (Eds), Geologia do Continente Sul-Americano - Evolução da Obra de Fernando Flávio Marques de Almeida, Beca: São Paulo, p. 37-42.

ASSINE ML. 2003. Sedimentação na Bacia do Pantanal Mato-Grossense, Centro-Oeste do Brasil. Instituto de Geociências e Ciências Exatas, Universidade Estadual Paulista - UNESP, Rio Claro, Tese de Livre Docência, $106 \mathrm{p}$.

ASSINE ML. 2004. A Bacia Sedimentar do Pantanal MatoGrossense. In: Mantesso-Netto V et al. (Eds), Geologia do Continente Sul-Americano - Evolução da Obra de Fernando Flávio Marques de Almeida, Beca: São Paulo, p. 61-74.
ASSINE ML. 2008. Ambientes de leques aluviais. In: Pedreira da Silva AJ (Ed), Ambientes de Sedimentação Siliciclástica do Brasil. Paulo: Beca, 5271 p.

ASSINE ML. 2010. Pantanal Mato-Grossense: uma paisagem de exceção. In: Modenesi-Gauttieri MC et al. (Eds), A Obra de Aziz Nacib Ab'Saber. São Paulo: Beca-Ball Editions, p. 464-489.

ASSINE ML AND SOARES PC. 2004. Quaternary of the Pantanal, West-central Brazil. Quaternary Int 114: 23-34.

ASSUMPÇÃO M, BIANCHI M, JULIÀ J, DIAS FL, FRANÇA GS, NASCIMENTO R, DROUET S, PAVÃO CG, ALBUQUERQUE DF AND LOPES AEV. 2013a. Crustal thickness map of Brazil: Data compilation and main features. South Am Earth Sci 43: 74-85.

ASSUMPÇÃO M, FENG M, TASSARA A AND JULIÀ J. 2013b. Models of crustal thickness for South America from seismic refraction, receiver functions and surface wave tomography. map of Brazil: Data compilation and main features. Tectonophysics 609: 82-96.

ASSUMPÇÃO M, FERNANDES CM AND FACINCANI EM. 2009b. O sismo do Pantanal de 15/06/2009 de magnitude 4,8. In: Congresso Brasileiro de Geofísica, 11, Salvador, Bahia. Anais... Salvador, Bahia: 2009a.

ASSUMPÇÃO M, LOPER AEV, ZEVALLOS I, FERREIRA JM AND NASCIMENTO A. 2009a. Intraplate Stress Field in Brazil from Earthquake Focal Mechanisms. In: Conferencia Internacional en Homenaje a Alberto Giesecke. Anais..., Lima, Peru: 2009b.

ASSUMPÇÃO MAND SUÁREZ G. 1988. Source mechanisms of moderate-size earthquakes and stress orientation in midplate South America. Geophys J Int 92(2): 253-267.

BRANNER JC. 1912. Earthquakes in Brazil. Bull Seismol Soc Am 2(2): 105-117.

CHAKRAVARTY IM, ROY JD AND LAHA RG. 1967. Handbook of Methods of Applied Statistics 1: 392-394.

EARTH EXPLORER. 2013a. United States Geological Survey. Landsat 8 Images. Channels 1, 2, 3, 4, 5, 6, 7 and 8. Orbit 225, point 072. Accessed on September 7, 2013.

EARTH EXPLORER. 2013b. United States Geological Survey. Landsat 8 Images. Channels 1, 2, 3, 4, 5, 6, 7 and 8. Orbit 225, point 073. Accessed on September 7, 2013.

EARTH EXPLORER. 2013c. United States Geological Survey. Landsat 8 Images. Channels 1, 2, 3, 4, 5, 6, 7 and 8. Orbit 225, point 074. Accessed on September 7, 2013.

EARTH EXPLORER. 2013d. United States Geological Survey. Landsat 8 Images. Channels 1, 2, 3, 4, 5, 6, 7 and 8. Orbit 226, point 072. Accessed on September 7, 2013.

EARTH EXPLORER. 2013e. United States Geological Survey. Landsat 8 Images. Channels 1, 2, 3, 4, 5, 6, 7 and 8. Orbit 226, point 073. Accessed on September 7, 2013.

EARTH EXPLORER. 2013f. United States Geological Survey. Landsat 8 Images. Channels 1, 2, 3, 4, 5, 6, 7 and 8. Orbit 226, point 073. Accessed on September 7, 2013. 
EARTH EXPLORER. 2013g. United States Geological Survey. Landsat 8 Images. Channels 1, 2, 3, 4, 5, 6, 7 and 8. Orbit 227, point 072. Accessed on June 5, 2013.

EARTH EXPLORER. 2013h. United States Geological Survey Landsat 8 Images. Channels 1, 2, 3, 4, 5, 6, 7 and 8. Orbit 227, point 073. Accessed on June 5, 2013.

EARTH EXPLORER. 2013i. United States Geological Survey Landsat 8 Images. Channels 1, 2, 3, 4, 5, 6, 7 and 8. Orbit 227, point 074. Accessed on June 5, 2013.

ECKEL EB, MILTON C AND SULSONA PT. 1959. Geology and mineral resources of Paraguay-a reconnaissance, with sections on Igneous and metamorphic rocks and soils. Geological Survey Professional Paper, 110 p.

FACINCANI EM. 2007. Geomorfologia e Geologia do Cenozóico do Médio Vale do Rio Aquidauana, Borda Sudeste da Bacia do Pantanal, MS. Instituto de Geociências e Ciências Exatas, Universidade Estadual Paulista, UNESP, Rio Claro, Relatório de Pós-Doutorado, $100 \mathrm{p}$.

FACINCANI EM, ASSUMPÇÃO MS, ASSINE ML AND FRANÇA GLSA. 2011. Sismicidade da Bacia do Pantanal Mato-Grossense. In: Simpósio Nacional de Estudos Tectônicos (SNET), 13. Anais..., Campinas, São Paulo, p. 314-317.

FACINCANI EM, ASSUMPCAO MS, ASSINE ML, FRANCA GSLA, PARANHOS FILHO AC AND GAMARRA RM. 2012. Terremotos no Pantanal. In: Ferreia FMNS et al. (Eds), Pantanal: perspectivas históricas e culturais. Campo Grande, MS: Editora da UFMS, p. 87-99.

FERNANDES E. 2007. Análise espacial da estrutura e organização dos elementos da paisagem regional da Baixa Nhecolândia - Pantanal do Mato Grosso do Sul. Tese de Doutorado, Departamento de Geografia. Faculdade de Filosofia, Letras e Ciências Humanas, Universidade de São Paulo, São Paulo, 174 p.

FÚLFARO VJ, SAAD AR, SANTOS MV AND VIANNA RB. 1982. Compartimentação e evolução tectônica da Bacia do Paraná. R B Geoc 12(4): 590-611.

FURQUIM SAC, GRAHAM R, BARBIÉRO L, QUEIROZ NETO JPDE AND VIDAL-TORRADO P. 2010. Soil mineral genesis and distribution in a saline lake landscape of the Pantanal wetland, Brazil. Geoderma 154: 518-528.

GIS DEVELOPMENT TEAM. 2015. QGIS Geographic Information System. Version 2.8 Wien.

HASUI YA. 1990. Neotectônica aspectos fundamentais da tectônica ressurgente no Brasil. In: Workshop sobre a tectônica e sedimentação cenozóica continental no sudeste brasileiro. Anais..., p. 1-31.

HASUI YA. 2010. Grande Colisão Pré-Cambriana do Sudeste Brasileiro e a Estruturação Regional. Geociências 29(2): 141-169.

IBGE - INSTITUTO BRASILEIRO DE GEOGRAFIA E ESTATÍSTICA. 2011. Together with ASF/AADN - Alaska
Satellite Facility. Satellite Image. ALOS (Advanced Land Observing Satellite) AVNIR-2 (Advanced Visible and Near Infrared Radiometer type 2) - JAXA Japan Aerospace Exploration Agency. Channels 1, 2, 3 and 4. Orbit 1086. CD-ROM. February $2^{\text {nd }}, 2011$.

KIMBALL ET AL. 2013. GIMP: GNU Image Manipulation Program. Versão 2.8.4. Em português. Available at: http:// www.gimp.org/.

KRUSKAL WH. 1957. Historical notes on the Wilcoxon unpaired two-sample test. J Am Stat Assoc 52: 356-360.

LOMBARDO U AND VEIT H. 2014. The origin of oriented lakes: Evidence from the Bolivian Amazon. Geomorphology 204: 502-509.

LUNA MCMDM, PARTELI EJR, DURÁN O AND HERRMANN HJ. 2011. Model for the genesis of coastal dune fields with vegetation. Geomorphology 129: 215 224.

LUNA MCMDEM, PARTELI EJR AND HERRMANN HJ. 2012. Model for a dune Field with an exposed water table. Geomorphology 159-160: 169-177.

MELO JHG. 1989. The malvinokaffric realm in the Devonian of Brazil. In: MecMillan NJ, Embry AF and Glass DJ (Eds), Devonian of the World. International Symposium on the Devonian System, 2, Calgary. Proceeding..., Calgary, p. 669-703.

MENDES D. 2008. Filtros passa-baixas ponderados e dados SRTM aplicados ao estudo do pantanal da Baixa Nhecolândia, MS: Aspectos tectônicos e de distribuição de lagoas hipersalinas. Dissertação de Mestrado, Instituto de Geociências, Universidade de São Paulo, 209 p. (Unpublished).

MENDES D, ALMEIDA TIR, FERNANDES E AND SIGOLO JB. 2006. Utilização de imagens SRTM para a confecção de perfis altimétricos em varredura na baixa Nhecolândia, Pantanal, MS: Considerações sobre a atividade neotectônica. In: Simpósio de Geotecnologias no Pantanal, 1, Anais..., Campo Grande, p. 200-209.

MIOTO CL, PARANHOS FILHO AC AND ALBREZ EDOA. 2012. Contribuição à caracterização das sub-regiões do Pantanal. R Entre-Lugar 3(6): 165-180.

MIRANDA EEDE. 2005. Brasil em Relevo. Campinas: Embrapa Monitoramento por Satélite.

OLIVEIRA APG. 2014. Contribuição à caracterização do Pantanal Nhecolândia, Mato Grosso do Sul - Brasil. Tese de Doutorado, Programa de Pós-Graduação em Tecnologias Ambientais, Universidade Federal de Mato Grosso do Sul, $91 \mathrm{p}$.

PARANHOS FILHO AC, NUMMER A, ALBREZ EDOA, RIBEIRO AA AND MACHADO RA. 2013. Study of structural lineaments in Pantanal (Brazil) using remote sensing data. An Acad Bras Cienc 85: 913-922.

RABELO L AND SOARES PC. 1999. Lineamento Transbrasiliano e neotectônica na Bacia do Pantanal. In: 
Simpósio nacional de estudos tectônicos, 7, 1999, Lençóis. Anais..., p. 79-82.

RICCOMINI C AND ASSUMPÇÃO MA. 1999. Quaternary tectonics in Brazil. Episodes 22(3): 221-225.

SHIRAIWA S. 1994. Flexura da litosfera continental sob os Andes Centrais e a origem do Bacia do Pantanal. Tese de Doutorado, Instituto de Astronomia e Geofísica, Universidade de São Paulo, 86 p.

SOARES AP, SOARES PC AND ASSINE ML. 2003. Areias e lagoas do Pantanal, Brasil: herança paleoclimática? São Paulo: R B Geoc 33(2): 211-224.

SOARES PC, ASSINE ML AND RABELO L.1998. The Pantanal Basin: Recent Tectonics, Relationships to the Transbrasiliano Lineament. In: Simpósio brasileiro de sensoriamento remoto, 11, Santos, SP. Anais..., p. 459-469.
TRICART J. 1982. Paisagem e ecologia. Inter-Facies: escritos e documentos. São José do Rio Preto: Editora da UNESP, $55 \mathrm{p}$.

USSAMI N AND SHOZO S. 1999. Basement reactivation in as Sub-Andean foreland flexural bulge: the Pantanal, SW Brazil. Tectonics 18(1): 25-39.

WILHELMY H. 1958. Umlaufseen und dammuferseen tropischer tieflandflusse. Zeitschrift fur Geomorphologie 2: $27-54$

ZALÁN PV, WOLFF S, CONCEIÇÃO JCJ, VIEIRA LS, ASTOLFI MAM, APPI VT AND ZANOTTO OA. 1987. A divisão tripartite do Siluriano da Bacia do Paraná. R B Geoc 17(3): 242-252.

ZANI H AND ASSINE ML. 2011. Paleocanais no megaleque do rio Taquari: mapeamento e significado geomorfológico. R B Geoc 41(1): 37-43. 